\title{
The Antioxidant Effects of the Ethanolic Extract of Binahong Leaves Unilateral Ureteral Obstruction Rat Model
}

\author{
Anton Bahtiar*, Putri Sagita Utami, Melati Raisa Noor
}

Anton Bahtiar*, Putri Sagita

Utami, Melati Raisa Noor

Department of Pharmacology and Toxicology, Faculty of Pharmacy, Universitas Indonesia, Kampus UI Depok, 16424, West Java, INDONESIA.

\section{Correspondence}

\section{Anton Bahtiar}

Department of Pharmacology and Toxicology, Faculty of Pharmacy, Universitas Indonesia, Kampus UI Depok, 16424, West Java, INDONESIA.

E-mail: anton.bahtiar@ui.ac.id

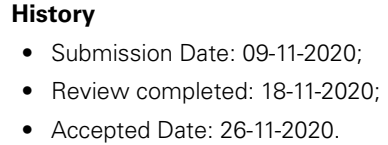

- Submission Date: 09-11-2020;

- Review completed: 18-11-2020;

- Accepted Date: 26-11-2020.

DOI : 10.5530/pj.2021.13.26

Article Available online

http://www.phcogj.com/v13/i1

Copyright

(C) 2021 Phcogj.Com. This is an openaccess article distributed under the terms of the Creative Commons Attribution 4.0 International license.

\begin{abstract}
Background: Chronic kidney injury produced free radicals. In a previous study, the ethanolic extract of binahong leaves (Anredera cordifolia (Ten.) Steenis) has a flavonoid content, quercetin, a protective free radical effect. This study aims to determine the impact of binahong leaves against chronic kidney damage in Sprague Dawley rats. Methods: To this end, we developed a chronic kidney injury animal model by Unilateral Ureteral Obstruction (UUO) method. We randomly divided rats into six groups. Group I is the Sham group; Group II is the negative control group; Group III is the positive control group (losartan $1.18 \mathrm{mg} / \mathrm{kg} \mathrm{BW}$ ); Group IV is Dose I of binahong leaves extract $75 \mathrm{mg} / \mathrm{kg} \mathrm{BW);} \mathrm{Group} \mathrm{V} \mathrm{is} \mathrm{Dose} \mathrm{II} \mathrm{binahong}$ leaves extract $150 \mathrm{mg} / \mathrm{kg} \mathrm{BW);} \mathrm{Group} \mathrm{VI} \mathrm{is} \mathrm{Dose} \mathrm{III} \mathrm{binahong} \mathrm{leaves} \mathrm{extract} 300 \mathrm{mg} / \mathrm{kg} \mathrm{BW}$ ). We administered losartan and binahong extracts on day 14 after UUO treatment. The plasma was examined for the superoxide dismutase (SOD) enzyme activity, catalase enzyme activity, and malondialdehyde (MDA). All statistical analyzes were processed using the Statistical Program of Social Sciences (SPSS) software for Windows, version 16. The measured values of the parameters were expressed in mean \pm SD. The difference test between groups was evaluated by ANOVA (Analysis of Variance) followed by LSD (Least Significant Difference) with a degree of significance (p) $<0.05$ if the data distribution was normal and homogeneous. If the distribution of data is not normal and not homogeneous use non-parametric Kruskal Wallis analysis. Results: The results showed that UUO produced high MDA levels, whereas SOD activity and catalase activity were decreased compared with the Sham group. Administration of binahong extracts could reduce the MDA amount and increased the SOD and catalase activity. Conclusion: Binahong leaves extracts showed antioxidant activity to prevent kidney injury in UUO model rats.

Key words: Anredera cordifolia, Chronic kidney injury, Unilateral Ureteral Obstruction, Binahong.
\end{abstract}

\section{INTRODUCTION}

Kidney disease is a disease that affects the world's population. In 2010, it was known that 2.62 million people received dialysis in all world. Overall, there are 5-10 million people who died because of kidney disease every year. Apart from that, kidney disease is also associated with a significant economic burden. The need for dialysis is projected to double by 2030 .

Injury to the kidneys can lead to acute kidney injury (AKI) and chronic kidney diseases (CKD). ${ }^{2}$ When the kidney injury is mild or acute (AKI) occurs, tissue repair mechanisms can usually restore kidney function. However, suppose the repair mechanism is compromised or the stimulus causing injury remains. In that case, AKI can develop into a chronic disorder (CKD), a condition characterized by organ remodeling and fibrosis. ${ }^{3}$ Fibrosis is a feature typical of CKD. ${ }^{2}$ Fibrosis is also closely associated with failed manifestations; fibrosis is associated with a poor long-term prognosis. ${ }^{4}$

The unilateral ureteral obstruction (UUO) model is known to illustrate AKI and CKD conditions. The obstruction's sensitive nature leads to AKI, while its continuation obstruction provides CKD histological features in 1 to 2 weeks. ${ }^{2}$
To date, there is no curative treatment for CKD. Renal protection therapy currently uses class antihypertensive drugs angiotensin-converting enzyme inhibitor (ACEi) and/or angiotensin II receptor blockers (ARBs), which have been shown to reduce glomerular hyperfiltration and albuminuria. ${ }^{5}$ The development of new drugs generally aims to cure or slow the progression of related diseases. The target of a drug is never independent of the condition's pathophysiology being attempted to handle it.

The extract from the leaves of binahong (Anredera cordifolia (Ten) Steenis) is known to contain flavonoids that have antioxidant activity ward off free radicals. ${ }^{6} \mathrm{~A}$ dose of $150 \mathrm{mg} / \mathrm{kg}$ BW binahong leaf ethanolic extract improved renal function in gentamicin-piroxicam-induced renal disease model rats in previous research. The current study aims to determine the impact of binahong leaves against chronic kidney damage in Sprague Dawley rats using unilateral ureteral obstruction rats model.

\section{RESEARCH DESIGN}

The research design used in this research is experimental. Experiential research is a study that looks for the influence between one variable and another with conditions determined by the researcher.

Cite this article: Bahtiar A, Utami PS, Noor MR. The Antioxidant Effects of the Ethanolic Extract of Binahong Leaves Unilateral Ureteral Obstruction Rat Model. Pharmacog J. 2021;13(1): 1858. 


\section{MATERIAL AND METHODS}

All the chemicals are purchased from Merck or Sigma except when specifically mentioned. Aqua dest (PT. Brataco, Indonesia), ketamine (Agrovet, Peru), xylazine (Interchemie, Netherlands), Triton X-100 (Merck, Germany), EDTA (Merck, Germany), K2HPO4 (Merck, Germany), KH2PO4 (Merck, Germany), Creatinine FS Kit (DiaSys, Germany), CheKineTM Lipid Peroxidation (MDA) Assay Kit (Abbkine Inc, China), CheKineTM Superoxide Dismutase (SOD) Activity Assay Kit (Abbkine Inc, China), CheKineTM Catalase (CAT) Activity Assay Kit (Abbkine Inc, China), PBS / Phosphate Buffer Saline (HiMedia Laboratories Pvt Ltd, India), methanol (Merck, Germany), 70\% ethanol (Erkamed, Indonesia), povidone-iodine (PT.Mahakam Beta Farma, Indonesia), ddH2O (PT.Ikaparhmindo Putramas, Indonesia).

The plant determination was carried out at the Bogoriense Herbarium, Botany-Biology Research Center, LIPI Cibinong, Indonesia, with certificate no. 2285/IPH.1.01/If.07/IX/2018. Binahong leaves are obtained from the Scientific Tourism Area, Bogor Spice, and Medicinal Research Institute (Balitro) Bogor, Indonesia.

\section{Plant extracts preparation}

$20 \mathrm{~kg}$ of fresh leaves of Binahong is washed and air-dried for four days. After being dried, it is powdered into $1090 \mathrm{gr}$. The powder obtained was extracted by maceration using $96 \%$ ethanol, then filtered using filter paper. Maceration results are evaporated using a rotary evaporator to get a concentrated extract that can still be poured.

\section{Animal treatment}

In this experiment, all animals were used following the Faculty of Medicine's animal care guidelines, Universitas Indonesia ethic committee with Ethical certificate approval no: KET-94/UN2.F1/ETIK/ PPM.00.02/2020.

Thirty-six white male rats weight of 150-250 grams used in this study, obtained from the Non-Ruminansa and Animal Hope Department, Faculty of Animal Husbandry, Bogor Agricultural University (IPB), Bogor. Rats were given exposure to the dark and light places for 12 hours, each with a temperature of $25 \pm 2^{\circ} \mathrm{C}$. Rats were divided into six groups; they are Group I is the Sham group, Group II is the negative control group, Group III is the positive control group (losartan 1.18 $\mathrm{mg} / \mathrm{kg} \mathrm{BW}$ ), Group IV is Dose I of binahong leaves extract $75 \mathrm{mg} /$ $\mathrm{kg} \mathrm{BW}$ ), Group V is Dose II binahong leaves extract $150 \mathrm{mg} / \mathrm{kg} \mathrm{BW}$ ), Group VI is Dose III binahong leaves extract $300 \mathrm{mg} / \mathrm{kg} \mathrm{BW}$ ). Each substance was given after UUO treatment for 14 days. The parameters examined in each group are the superoxide dismutase (SOD) enzyme activity, catalase enzyme activity, and malondialdehyde (MDA).

\section{Unilateral ureteral obstruction model rats}

Unilateral Ureteral Obstruction (UUO) is a model currently widely used to study obstruction nephropathy. In rats treated with UUO, the left ureter was tied with silk thread 4.0 at 2 points; then, between these points, the ureter was cut using surgical scissors. In normal control rats, Sham surgery was performed. Namely, the left ureter was only identified but not treated with UUO. ${ }^{7}$ Male rats were preferred because the female reproductive organs complicate the surgical procedure because their organs are more complicated. It is also essential to maintain the body temperature of the animal being operated on and also to use a quality binocular microscope. ${ }^{8}$

\section{Determination of malonaldehyde (MDA)}

MDA is a product of lipid peroxidation produced from direct damage of polyunsaturated fatty acids (PUFAs) during exposure to oxidative agents ${ }^{9}$. MDA can bind with thiobarbituric acid to form a thiobarbituric
acid-MDA complex, quantified colorimetrically at a wavelength of $532 \mathrm{~nm}$. The determination of MDA levels is carried out based on the procedure in the CheKineTM Lipid Peroxidation (MDA) Assay Kit.

\section{Determination of superoxide dismutase (SOD) activity}

SOD activity measurements were measured according to the CheKineTM Superoxide Dismutase (SOD) Activity Assay Kit procedure. Superoxide anion (O2-) is produced by catalyzing the reaction of xanthine oxidase. O2- reacts with the tetrazolium salt (WST-8) and dissolves in water to give the colored formazan. SOD can counteract the O2-

\section{Determination of catalase activity}

The catalase activity measurement was measured according to the procedure from the CheKineTM Catalase (CAT) Activity Assay Kit. The determination of catalase activity is based on the reaction of catalase with methanol in the presence of $\mathrm{H} 2 \mathrm{O} 2$. The formaldehyde formed can be measured colorimetrically at a wavelength of $540 \mathrm{~nm}$.

\section{Determination of plasma creatinine}

This plasma creatinine measurement method refers to the Creatinine FS kit (DiaSys) protocol, adapted from the Jaffe Method with the principle that creatinine will form an orange-red complex with alkaline picrate solution.

\section{Statistical analysis}

All statistical analyzes were processed using the Statistical Program of Social Sciences (SPSS) software for Windows, version 16. The measured values of the parameters were expressed in mean \pm SD. The difference test between groups was evaluated by ANOVA (Analysis of Variance) followed by LSD (Least Significant Difference) with a degree of significance $(p)<0.05$ if the data distribution was normal and homogeneous. If the distribution of data is not normal and not homogeneous use non-parametric Kruskal Wallis analysis.

\section{RESULT}

UUO has the highest ratio of kidney weight and body weight. The condition of an enlarged kidney in length is called hydronephrosis, as shown in Table 1. Hydronephrosis is a condition where there is swelling of the kidneys due to urine not being able to flow from the kidneys to the bladder due to blockage or obstruction of the ureter. ${ }^{10}$ Binahong extract dose of $75 \mathrm{mg} / \mathrm{kg} \mathrm{BW}$ could reduce the hydronephrosis.

UUO produced a high amount of malonaldehyde, whereas reduced SOD and catalase activity. Administration of Binahong leaves extracts could reduce the amount of MDA besides increasing the SOD and catalase activity, as shown in Table 2.

UUO increased plasma creatinine, and the administration of binahong leaves extracts could reduce creatinine, as shown in Table 3.

\section{DISCUSSION}

Unilateral ureteral obstruction (UUO) is a well-known model in which urine accumulates in the renal pelvis, leading to hydronephrosis with renal atrophy and interstitial fibrosis. ${ }^{11}$

The incidence of chronic kidney diseases increases and current treatments are limited to angiotensin II receptor blockers and angiotensin-converting enzyme inhibitors. Losartan is an angiotensin II receptor inhibitor and can inhibit interstitial fibrogenesis by modulating nitric oxide synthase (NOS) isoforms and cyclooxygenase-2 (COX-2) expression ${ }^{12}$, and decreasing oxidative stress in the kidneys ${ }^{13}$ in rats with UUO. Therefore, losartan was selected as positive controls for the prevention of renal fibrosis in the UUO model. 
Table 1: Kidney weight /Bodyweight ratio.

\begin{tabular}{cc}
\hline Groups & Average \pm SD $(\mathrm{nmol} / \mathrm{g})$ \\
\hline Normal group & $4 \times 10^{3} \pm 0.8 \times 10^{3}$ \\
Negative group & $21 \times 10^{3} \pm 2 \times 10^{3}$ \\
Positive group & $9 \times 10^{3} \pm 2.9 \times 10^{3}$ \\
Binahong dose 1 & $12 \times 10^{3} \pm 1.1 \times 10^{3}$ \\
Binahong dose 2 & $14 \times 10^{3} \pm 4 \times 10^{3}$ \\
Binahong dose 3 & $17 \times 10^{3} \pm 3 \times 10^{3}$ \\
\hline
\end{tabular}

Note: Normal group administered carboxymethylcellulose sodium $0.5 \%$; Positive group: Losartan $1.18 \mathrm{mg} / 200 \mathrm{gBW}$; Binahong dose 1: $75 \mathrm{mg} / \mathrm{kgBW}$; Binahong dose 2: $150 \mathrm{mg} / \mathrm{kgBW}$; Binahong dose 3: $300 \mathrm{mg} / \mathrm{kgBW}$

Table 2: Effects of Binahong leaves extracts on malonaldehyde, superoxide dismutase activity, and catalase activity on UUO model rats.

\begin{tabular}{cccc}
\hline Groups & $\begin{array}{c}\text { MDA concentration } \\
\text { Average } \pm \text { SD } \\
(\mathrm{nmol} / \mathrm{g})\end{array}$ & $\begin{array}{c}\text { SOD activity } \\
\text { Average } \pm \text { SD } \\
(\mathrm{U} / \mathrm{mL}))\end{array}$ & $\begin{array}{c}\text {. Catalase activity } \\
\text { Average } \pm \text { SD } \\
(\mathrm{nmol} / \mathrm{g})\end{array}$ \\
\hline Normal group & $0.161 \pm 0.009$ & $108.38 \pm 1.945$ & $43.29 \pm 3.6$ \\
Negative group & $0.380 \pm 0.003$ & $32.50 \pm 8.132$ & $31.30 \pm 7.9$ \\
Positive group & $0.082 \pm 0.006$ & $96.00 \pm 1.05$ & $47.74 \pm 5.8$ \\
Binahong dose 1 & $0.103 \pm 0.003$ & $81.75 \pm 4.21$ & $30.41 \pm 2.6$ \\
Binahong dose 2 & $0.198 \pm 0.011$ & $124.5 \pm 5.87$ & $40.80 \pm 6.9$ \\
Binahong dose 3 & $0.153 \pm 0.051$ & $104.75 \pm 3,96$ & $60.77 \pm 14.1$ \\
\hline
\end{tabular}

Note: Normal group administered carboxymethylcellulose sodium 0.5\%; Positive group: Losartan $1.18 \mathrm{mg} / 200$ gBW; Binahong dose 1: $75 \mathrm{mg} / \mathrm{kgBW}$; Binahong dose 2: $150 \mathrm{mg} / \mathrm{kgBW}$; Binahong dose 3: $300 \mathrm{mg} / \mathrm{kgBW}$

Table 3: Plasma creatinine.

\begin{tabular}{cccc}
\hline Groups & Before & After & \\
\hline Normal group & $1.037 \pm 0.16$ & $1.112 \pm 0.31$ & 0.075 \\
Negative group & $1.519 \pm 0.21$ & $2.035 \pm 0.33$ & 0.516 \\
Positive group & $0.819 \pm 0.18$ & $1.147 \pm 0.18$ & 0.328 \\
Binahong dose 1 & $1.707 \pm 0.38$ & $2.024 \pm 0.53$ & 0.317 \\
Binahong dose 2 & $1.702 \pm 0.25$ & $1.720 \pm 0.33$ & 0.018 \\
Binahong dose 3 & $1.262 \pm 0.33$ & $1.236 \pm 0.26$ & -0.0026 \\
\hline
\end{tabular}

Note: Normal group administered carboxymethylcellulose sodium 0.5\%; Positive group: Losartan $1.18 \mathrm{mg} / 200 \mathrm{gBW}$; Binahong dose 1: $75 \mathrm{mg} / \mathrm{kgBW}$; Binahong dose 2: $150 \mathrm{mg} / \mathrm{kgBW}$; Binahong dose 3: $300 \mathrm{mg} / \mathrm{kgBW}$

Anredera cordifolia (Ten.) Steenis has heart-shaped green leaves, in Indonesia A.cordifolia is also called binahong. Based on several scientific studies, it is said that A. cordifolia has been shown to have pharmacological activity in improving kidney function, as an antibacterial, antifungal, antiviral, protease inhibitors, xanthine oxidase inhibitors, antidiabetic, antihypertensive, vasodilator, diuretic, antiobesity, hypolipidemic, antioxidant, gastroprotective, hepatoprotective, cytotoxic, anti-inflammatory, analgesic, and wound healing. In improving renal function, the ethanol extract of A. cordifolia leaves with doses of 50,100 , and $150 \mathrm{mg} / \mathrm{kg}$ BW applied for four weeks can reduce the concentration of urea and serum creatinine in rats induced by gentamycin and piroxicam.

MDA in the UUO kidneys was increased as indicatives of the renal oxidative stress-induced injury, which could be significantly reduced by the administration of binahong leaves extracts. In addition, there was a lower level of SOD in the UUO kidneys as compared to the normal ones, suggesting the endogenous regulation to counteract the renal oxidative stress. Reactive oxygen species (ROS) are recognized mechanism in the pathogenesis of UUO in experimental studies. Increased lipid peroxidation has found in renal cortexes of UUO animals. It has been shown that oxidative stress in UUO contributes to the development of tubulointerstitial lesions and renal fibrosis. Various factors with complex cellular and molecular interactions have also been proposed as possible causes that lead to tubulointerstitial lesions and renal fibrosis. ${ }^{14}$ Binahong leaves extract restored the counterregulatory rise of renal SOD in UUO rats, possibly because the antioxidant effects have been achieved. ${ }^{15}$

Obstruction of the ureter can lead to complex renal injury and insufficiency, as well as protein changes in both serum and urine. Although increased $\mathrm{Up} / \mathrm{Ucr}$ ratio and serum creatinine levels indicate renal injury, these markers cannot distinguish between specific nephropathies.?

\section{CONCLUSION}

Based on the analysis conducted, it can be concluded that binahong leaves extracts seen promising to used on the chronic kidney diseases by reducing free radical that produced during progression of diseases.

\section{CONFLICTS OF INTEREST STATEMENT}

The authors declare no conflicts of interest in this research.

\section{ACKNOWLEDGMENT}

This work was supported by The Ministry of Research and Technology/ BRIN Republic Indonesia grant NKB-87/UN2.RST/HKP.05.00/2020 to $\mathrm{AB}$. 


\section{REFERENCES}

1. Luyckx, V. A., Tonelli, M. \& Stanifer, J. W. The global burden of kidney disease and the sustainable development goals. Bull. World Health Organ. 96, 414422D (2018).

2. Ucero, A. C. et al. Unilateral ureteral obstruction: beyond obstruction. Int. Urol. Nephrol. 46, 765-776 (2014).

3. Hewitson, T. D., Holt, S. G. \& Smith, E. R. Progression of Tubulointerstitial Fibrosis and the Chronic Kidney Disease Phenotype - Role of Risk Factors and Epigenetics . Frontiers in Pharmacology 8, 520 (2017).

4. Nogueira, A., Pires, M. J. \& Oliveira, P. A. Pathophysiological Mechanisms of Renal Fibrosis: A Review of Animal Models and Therapeutic Strategies. In Vivo 31, 1-22 (2017).

5. Breyer, M. D. \& Susztak, K. Developing Treatments for Chronic Kidney Disease in the 21st Century. Semin. Nephrol. 36, 436-447 (2016).

6. Yunarto, N., Aini, N., Oktoberia, I., Sulistyowati, I. \& Kurniatri, A. Aktivitas Antioksidan serta Penghambatan HMG CoA dan Lipase dari Kombinasi Ekstrak Daun Binahong-Rimpang Temu Lawak. J. Kefarmasian Indones. 89-96 (2019). doi:10.22435/jki.v9i2.1930

7. Yuan, Y., Zhang, F., Wu, J., Shao, C. \& Gao, Y. Urinary candidate biomarker discovery in a rat unilateral ureteral obstruction model. Sci. Rep. 5, 9314 (2015)
8. Martínez-Klimova, E., Aparicio-Trejo, O. E., Tapia, E. \& Pedraza-Chaverri, J. Unilateral Ureteral Obstruction as a Model to Investigate Fibrosis-Attenuating Treatments. Biomolecules 9, 141 (2019)

9. Kulkarni, R., Deshpande, A., Saxena, R. \& Saxena, K. A study of serum malondialdehyde and cytokine in tuberculosis patients. J. Clin. Diagn. Res. 7 2140-2142 (2013)

10. Hesketh, E. E. et al. A murine model of irreversible and reversible unilateral ureteric obstruction. J. Vis. Exp. 52559 (2014). doi:10.3791/52559

11. Chevalier, R. L., Forbes, M. S. \& Thornhill, B. A. Ureteral obstruction as a model of renal interstitial fibrosis and obstructive nephropathy. Kidney Int. 75, 11451152 (2009)

12. Manucha, W., Oliveros, L., Carrizo, L., Seltzer, A. \& Vallés, P. Losartan modulation on NOS isoforms and COX-2 expression in early renal fibrogenesis in unilatera obstruction. Kidney Int. 65, 2091-2107 (2004).

13. Wolf, G. \& Ritz, E. Combination therapy with ACE inhibitors and angiotensin I receptor blockers to halt progression of chronic renal disease: Pathophysiology and indications. Kidney Int. 67, 799-812 (2005).

14. Dursun, M. et al. Protective effect of hydrogen sulfide on renal injury in the experimental unilateral ureteral obstruction. Int. Braz J Urol 41, 1185-1193 (2015)

15. Susanti, H. Total phenolic content and antioxidant activities of binahong (Anredera cordifolia.). J. Kedokt. dan Kesehat. Indones. JKKI, Vol 10, No 2 (2019)DO - 10.20885/10.20885/JKKI. Vol10.Iss2.art9 (2019).

\section{ABOUT AUTHORS}

- Anton Bahtiar obtained his PhD degree in 2010 from Nara Institute of Science and Technology, Japan. Currently, He is lecturer and researcher at faculty of pharmacy, Universitas Indonesia since 1998. He is also a head of Pharmacology and Toxicology Laboratory. His research projects are focus on Herbal medicine, and tried to solve the mechanism of action of herbal medicine, especially for osteoporosis and menopouse.

- Putri Sagita Utami obtained her Bachelor degree in 2020 from Faculty of Pharmacy, Universitas Indonesia. She is continue her education in Pharmacist profession programme. Her research focus on drug development for kidney diseases from Natural products in Department of Pharmacology and Toxicology of Faculty of Pharmacy Universitas Indonesia.

- Melati Raisa Noor obtained her Bachelor degree in 2020 from Faculty of Pharmacy, Universitas Indonesia. She is continue her education in Pharmacist profession programme. Her research focus on drug development for kidney diseases from Natural products in Department of Pharmacology and Toxicology of Faculty of Pharmacy Universitas Indonesia.

Cite this article: Bahtiar A, Utami PS, Noor MR. The Antioxidant Effects of the Ethanolic Extract of Binahong Leaves Unilateral Ureteral Obstruction Rat Model. Pharmacog J. 2021;13(1): 185-8. 